Volume: 11 Issue: 1 Year: 2014

\title{
What are the determinants of economic growth in Muslim countries?
}

\author{
Durmuş Alper Çamlıbel ${ }^{1}$
}

\begin{abstract}
Muslim countries are generally considered economically behind the non-Muslim countries, culturally conservative, authoritarian, and misogynistic. Although the Muslim population, as a whole, comprises an enormous economic potential, many Muslims in the world contend with poverty and illiteracy. Furthermore, economic disparity among Muslim nations is widening. This article examines the reasons behind economic inequalities among Muslim countries and explores whether Islam hinders economic growth or not. On the contrary to general belief that Islam hinders economic growth, this study showed that Islam by itself has no effect on economic prosperity in Muslim Countries. Using cross-country regression, this empirical research displayed that the adaptation of technology and scientific innovations, investment to human capital, human development, and economic freedom are significant and necessary for economic growth in Islamic countries.
\end{abstract}

Keywords: Islam, Economic Growth; Political Freedom; Economic Freedom; Human Development; Human Capital; Technology.

\section{Introduction}

Since Adam Smith the concept of economic growth and the question "What determines the rate of growth?" has been the main focus of economists. In the World, there are 48 states which are considered Muslim or Islamic countries. In these Muslim countries, at least 50 percent of people believe and practice Islamic rules. The Muslim countries are not geographically collected in only one specific region; rather they spread in the Middle East and North Africa regions, Europe and Eurasia regions, South and East Asia, and sub-Saharan Africa regions (Timmer and McClelland 2004).

Muslim countries are generally considered economically behind the non-Muslim countries, culturally conservative, authoritarian, and misogynistic. The teaching of Islam, however, advises to Muslim societies to realize democratic governance and market based economics. For many years,

\footnotetext{
${ }^{1}$ Ph.D., Turkish National Police, dacamlibel@yahoo.com
} 
Çamlıbel, D. A. (2014). What are the determinants of economic growth in Muslim countries? International Journal of Human Sciences, 11(1), 403-426. doi: 10.14687/ijhs.v11i1.2775

Islam has been familiar with the modern world's principles such as democratic governance, participation, consultation, rule of law, accountability (Timmer and McClelland 2004). Although the Muslim population, as a whole, comprises an enormous economic potential, many Muslims in the world struggle with poverty and illiteracy. Moreover, a wide range of economic disparity exists among Muslim countries while some have a high rate of GDP per capita and other do not.

This study explores the reasons for economic disparities among Muslim countries and to understand whether Islam hinders economic growth or not, the article also examines the determinants of economic growth in Islamic countries. The research question of the study is: What are the determinants of economic growth in Muslim countries? The research question was chosen to prove that Islam, merely, neither have positive nor negative impact on economic growth and there are also some other factors such as human development, economic freedom, political freedom, adaptation of technology and human capital, which effect the economic growth process of Muslim countries. The importance of this research is to scientifically demonstrate that Islam has no influence on economical growth of Muslim countries.

In this statistical analysis, the first section introduces a brief review of past literature on determinants of economic growth, discussion of theory and hypothesis. In the data section, dependent and independent variables will be defined, and summary statistics will be provided, as well. Analysis of the hypothesis and testing for violations of OLS assumptions will precede the analysis of the final model. In the final section, the research will be wrapped up and some suggestions will be made for future research.

\section{Literature Review}

According to some researchers, cultural norms determine economic growth and therefore researchers should include a nation's culture in their model (Huntington 1996; Landes 1999, Inglehart and Baker 2000). Religion is a significant component of culture and culture is commonly considered as a factor of economic growth. Recent studies have examined the impact of religion on growth (Guiso et.al., 2003; North and Gwin, 2004; Noland, 2005; Barro and McCleary, 2003) and stressed particular religious beliefs such as Islam, Hinduism, or Catholicism (Kuran, 2004; Fields, 2003). However, these studies could not reach a consensus on whether an economy established on Islamic principles hinders or promotes economic growth. Based on World Values Survey data, Guiso et.al (2003:280) claim that "Islam is negatively associated with attitudes that are conducive to economic growth" and they emphasize that among believers to the world's major religions, Muslim countries are the most "anti-market." 
Çamlıbel, D. A. (2014). What are the determinants of economic growth in Muslim countries? International Journal of Human Sciences, 11(1), 403-426. doi: 10.14687/ijhs.v11i1.2775

On the other hand, some scholars assert that Islamic values are consistent with contemporary world's market based economic principles. There are some studies which show that religious thoughts can positively affect economic growth. In his study Noland (2002) examined three-multi religious and multi-ethnic countries, namely India, Malaysia, and Ghana, to see the causal relationship between religion and economic performance. Like earlier studies by Barro and McCleary (2002) Noland could not find a robust relationship between adherence to a specific religion and national economic performance. Something as long lasting as religious membership is only a weak explanatory factor of something as changeable as macroeconomic performance. Their findings demonstrate that Islam promotes economic growth (Noland 2002; Barro and McCleary 2002). Barlow who examined cross-national growth among Islamic countries in the Middle East for the period of 1950 to 1972 and Collins and Bosworth who researched Total Factor Productivity (TFP) growth rates of Islamic countries for 1960 to 1973 and these scholars found that Islamic countries grow more rapidly than other developing countries (Barlow 1982, Collins and Bosworth 1996 as cited in Noland 2002).

There are a number of variables that might influence economic growth in Muslim countries and religion or culture is only one of the determinants of economic growth. If Islam cannot explain underperformance of economic growth in Muslim countries by itself, then what are the determinants of economic growth in Islamic states? Several factors may affect poor economic performance in the Muslim world. These include bad human development progress, poor economic freedom, lack of scientific and technologic development, unskilled and ill trained human capital and authoritarian political systems.

Furthermore, political and economic freedom can be considered as other determinants of economic growth. A vast number of studies in the literature have attempted to find the relation between political freedom-economic growth and economic freedom-economic growth. In the political science literature a number of empirical studies have found a positive relation between economic freedom and economic growth (Barro, 1991; Barro, 1995; Scully and Slottje, 1991; De Vanssay and Spindler, 1994). Gwartney et al. (1999) used a simple causality test to support the view that increases in economic freedom lead to higher growth rates, but higher growth rates do not lead to increases in economic freedom.

Lipset (1959:75) argued that economic growth leads to better political democracy within the nation and he stated "perhaps the most wide widespread generalized linking political system to other aspects of society is related to the state of economic development." Many empirical studies supported Lipset's argument, however, there is no agreement on the influence of political freedom 
Çamlıbel, D. A. (2014). What are the determinants of economic growth in Muslim countries? International Journal of Human Sciences, 11(1), 403-426. doi: 10.14687/ijhs.v11i1.2775

on economic growth in the literature. In their studies, Barro (1991, 2001, 2002), Barro and Sala-iMartin (1995), and Scully (1992) found the impact of a variety of political freedoms on economic growth. Goldsmith (1995) used both the Heritage Foundation measure of economic freedom and the Freedom House measure of political rights to show their relationship between the growth rate of GDP and political and economic freedom. He found that economic freedom and political freedom led to increases in GDP on the other hand, Ali (1997) performed his regression by adding economic freedom, political freedom and civil liberties to his economic growth regression finally he found only economic freedom was statistically significant and economic freedom is a more robust indicator of economic growth than political freedom and civil liberty

Farr, Lord, and Wolfenbarger (1998) analyzed the causal relationship among per capita GDP growth, economic freedom, and political freedom. Their findings showed the subsistence of a mutual causal relationship between economic freedom and growth in addition to a causal relationship between growth and political freedom. However, they could not find any causal relationship between political freedom and economic freedom.

Human development is another determinant of economic prosperity and it has significant impacts on economic growth. If an essential component of economic growth is allowing agents to learn and improve their comparative benefits, an increase in the skills and performances available to people should allow more of them to practice professions in which they are most prolific. From that aspect human development can be conceived as the releasing of restrictions that may have hindered profit maximization. Moreover, although the concept of human development comprises a wide range of issues, many of its components are highly correlated with the concept of human capital. Therefore, many of the elements of human development significantly overlap with human capital and human capital impacts the economic growth of a country. Human development is bound to have an influence on economic growth (Ranis 2004).

The concept of human development consists of a variety of elements and these elements have a separate effect on economic growth. Education, for instance, has a strong effect on labor productivity (Ranis 2004). The notion of human development suggests that human welfare depends on a variety of aspects, many of which are not well captured by conventional measures of economic income (Griffin and Knight, 1990; UNDP, 1990). Human development measures human wellbeing and it perceives health and education as essential outputs together with economic outputs. In classic measures of economic outcome, health and education's role is measured mainly by the production costs of outcomes, for instance education and health expenditures (Appleton and Teal 1998). 
Çamlıbel, D. A. (2014). What are the determinants of economic growth in Muslim countries? International Journal of Human Sciences, 11(1), 403-426. doi: 10.14687/ijhs.v11i1.2775

The area of human capital, in turn, is very broad and it defines characteristics of human being which can be gained and which increase income. In understanding the role of human capital as an input into development it is necessary to consider the possible links between human capital, other forms of capital, income and growth. It is generally thought to comprise of peoples knowledge and skills acquired partially through education. The Human capital theory concentrates on health and education as inputs to economic production.

Many prominent scholars argued that accumulation of knowledge and skills as well as economic development related to rapid technological progress thus development most likely depends on the quality of human capital (Becker, Murphy and Tamura 1990; Foster and Rosenzweig 1995). In his cross-country study Barro (1991) observed 98 countries between 1960 and 1985 and his study results showed that the growth rate of real per capita GDP is positively related to initial human capital. In his next book Barro (1995) emphasized the importance of education and health in economic growth. He concludes that physical capital effects a high endowment of human capital in a country. Gallup et al. (1998), Sachs and Warner (1997) emphasized the power of education and good health in human capital. According to them a well-developed labor capital will lead to better and more outcome than unskilled workers.

Furthermore, an efficient technology adaptation affects a country's development process and gives rapidity its economic growth. Ben Habib and Spiegel (1994), argued that human capital affected Total Factor Productivity Growth (TFPG) through its influence on the capability of a state to innovate and the capacity of using and adapting foreign technology.

Romer (1990) noted that a qualified of labor force explores new techniques in production and creates new products that cause technological growth. He also stated that those countries, which have a high skilled and experienced worker source and are more open to innovations, thus they tend to grow faster. Zipfel (2004) approached human capital like physical capital and claims both need investment for economic achievement, however, instead of machinery investment human capital focuses on investment in skills and knowledge. Therefore, human capital can only be measured indirectly.

\section{Theory and Hypothesis}

The growth theories have pointed out three determinants of growth: (i) capital accumulation, (ii) human capital (including learning), and (iii) research, development and innovation (Stern 1991). In this study two main economic growth theories guided readers to answer the study's research question: Neoclassical and endogenous growth theories. These theories draw the framework of the 
Çamlıbel, D. A. (2014). What are the determinants of economic growth in Muslim countries? International Journal of Human Sciences, 11(1), 403-426. doi: 10.14687/ijhs.v11i1.2775

research. In the 1950s and 1960s, economist Robert Solow improved a model- namely the neoclassical model- that would help transform the understanding of growth theory (Mankiw et al., 1995). Solow predicted that the inputs, physical capital and labor, did not comprise all of the information related to understanding the size, strength, and growth potential of a particular economy. Building on revolutionary work that enquired into the influences of technological progress on an economy, the neoclassical theory perceived that a considerable part of economic output is dependent on the proportion of technological advancement of the economy being studied. Solow included technology in the production function equation (Zipfel 2004).

In the 1980's, research on economic growth experienced another significant breakthrough as economists noticed that economic growth itself had to be included to the model without considering that technological change takes place outside of the model's framework, thus the theory called endogenous growth theory (Reischauer 1994; Barro, 2001). The new theory closed the gap of former theory, which was unable to explain "why" countries grew faster than others (Zipfel 2004) and it explicitly added human capital accumulation, education and learning into the new model. More specifically, the endogenous theory recognizes that the development of a nation's human capital and human development will lead to economic growth by means of the new forms of technological progress and efficient and effective means of output. Some theorists made significant contributions to endogenous growth theory and they noticed the importance of human capital in economic growth. Becker et al., (1990:13) stated that “...embodied knowledge and skills, and economic development depends on advances in technological and scientific knowledge, development presumably depends on the accumulation of human capital."

Zipfel (2004:11) approached human capital like physical capital. He claimed "human capital can be invested in; however, the emphasis is on knowledge and skills, things that do not have a particular physical manifestation but are embodied in the minds and writings of individuals and societies."

Dieckmann's (1996) analysis of cultural theory showed that endogenous growth theory can be used to explain the effect of cultural factors on economic growth. He argued that cultural characteristics such as religion, determine the economic growth rate of nations. Therefore, endogenous theory suggests that cultural determinants help researchers to understand the differences among the national growth rates.

Economic theory often assists researchers to empirically examine the causal relationships among variables (Farr et.al 1998). Economic theory indicates that economic freedom stimulates productive effort, and the influences effectiveness of resource use. Since the time of Adam Smith economists have argued that the freedom to choose and supply resources, competition in business, trade with 
Çamlıbel, D. A. (2014). What are the determinants of economic growth in Muslim countries? International Journal of Human Sciences, 11(1), 403-426. doi: 10.14687/ijhs.v11i1.2775

others and secure property rights are main goals for economic development. The new growth theory captured the attention on this issue. A number of recent empirical studies claim that economic freedom has significant impact on explaining cross-country variations in economic growth (de Vanssay and Spindler 1994; de Haan and Sturm 2000). However, Farr et.al (1998) claimed that there is no theory, which finds a sufficient relationship among measures of economic freedom, political freedom, and economic growth.

Using the logics of economic, neoclassical and endogenous theories this work seeks to better explain the determinants of economic growth in Muslim countries.

The following hypothesis will be tested while controlling for political freedom, and human capital.

H1: The level of human development in Muslim Countries has a significant effect on economic growth.

H2: Islam does not have an impact on economic growth.

H3: Economic freedom has a positive impact on economic growth.

H4: Technology has a positive effect on economic growth

\section{Data and Method}

Economic growth is generally measured as the annual percentage rate of growth in one or another of the country's major national income accounting aggregates, such as Gross Domestic Product (GDP). Data for the dependent variable, gross domestic product per capita index (in purchasing power parity terms in US dollars), were collected from the 2005 United Nations Development Program (UNDP) and the Human Development Index (HDI).

To measure the effect of Islam on economic growth, countries with at least 50 percent Muslim population are chosen and these data are collected from the 2005 CIA World Fact Book.

The data for Economic Freedom in Muslim countries are collected from the 2005 Index of Economic Freedom (IEF). The reason for choosing the IEF is that it is available for a wide range of countries for a great number of years. The Heritage Foundation/Wall Street Journal publishes an Index of Economic Freedom annually. Ten indicators are used: (1) Business Freedom, (2) Trade Freedom, (3) Fiscal Freedom, (4) Freedom from Government, (5) Monetary Freedom, (6) Investment Freedom, (7) Financial Freedom, (8) Property rights, (9) Freedom from Corruption, and (10) Labor Freedom. The 10 factors are averaged equally into a total score. Every numbers of 10 freedoms is ranked using a scale from 0 to 100. Scores are as follows: 80-100 Free, 70-79.9 Mostly Free, 60-69.9 Moderately Free, 50-59.9 Mostly Unfree, 0-49.9 Repressed. 
Çamlıbel, D. A. (2014). What are the determinants of economic growth in Muslim countries? International Journal of Human Sciences, 11(1), 403-426. doi: 10.14687/ijhs.v11i1.2775

The data for the Human Development in Muslim countries are collected from the 2005 Human Development Index (HDI). The United Nations Development Program (UNDP) has generated the Human Development Index (HDI) as a composite indicator, which gives equal weight to these indicators: real GDP per capita (measured at purchasing power equality in constant prices); life expectancy at birth; and educational achievement, measured by adult literacy (two-thirds weight) and integrated primary, secondary and tertiary registration ratios (one third weight) (UNDP, 1997). The report asserts that, "human development is a process of enlarging people's choices. The most critical of these wide-ranging choices are to live a long and healthy life, to be educated and to have access to resources needed for a decent standard of living. Additional choices include political freedom, guaranteed human rights and personal self-respect" (UNDP, 1990:1).

Human capital consists of many variables. A number of researchers have performed a variety of methods and used different variables for trying to appropriately summarize the essence of human capital. To explain how much of the growth in output per worker is associated with growth in physical and human capital per worker and how much is associated due to technology, growth rate of per worker human capital and total factor productivity (TFP) values are used.

"An economy's output is a positive function of physical and human capital given the technology. Assumptions of constant returns to scale and competitive factor markets make it possible to calculate the growth rate of output implied by the growth of physical and human capital; deviations of actual output from this implied growth rate are due to changes in technology, institutional change, failure of the twin assumptions of constant returns to scale and competitive factor markets, and other factors. These deviations are called growth in total factor productivity (TFP) although these deviations include much more than what is suggested by the word "productivity" and probably are more fairly called the "residual" or "Solow residual" in growth" (Baier, et al. 2002:1).

Baier, Dwyer, and Tamura's (2002) data for Human Capital and TFP -the level of technology- are employed to see these relationships. In their study they examined the relative significance of physical and human capital growth and TFP growth for output growth using a new, more inclusive data set than existing data sets. Baier, Dwyer, and Tamura's (2002) data set includes more countries for a longer period than other data sets. Their measure of human capital per worker in each country reveals both average education and average number of years employed. The average number of years of schooling for an employed person is calculated from registrations in primary and secondary schools and higher education in combination with the age distribution of the population. In addition, TFP is measured by taking countries' weighted average growth of outputs and inputs (Baier, Dwyer, and Tamura 2002).

The Political Freedom is measured by using the Freedom House 2005 Political Rights Index. The Political Rights index measures the degree of freedom in the electoral procedure, political pluralism 
Çamlıbel, D. A. (2014). What are the determinants of economic growth in Muslim countries? International Journal of Human Sciences, 11(1), 403-426. doi: 10.14687/ijhs.v11i1.2775

and participation, and functioning of government. The Freedom House rates political rights on a scale of 1 to 7 , with 1 representing the most free and 7 representing the least free. A rating of 1 indicates free and fair elections, political competition, and autonomy for all citizens, including minority groups. A rating of 2 indicates that a country is less free--there may be some corruption, violence, political discrimination against minorities, and military influence on politics. These same factors play a progressively larger role in countries with a ranking of 3, 4, or 5--citizens of these countries typically experience some political rights (e.g. freedom to organize somewhat controversial groups, reasonably free referenda) along with more damaging influences (e.g. civil war, heavy military involvement, one-party dominance).

The purpose of this paper is to examine whether or not Islam, economic freedom, technological advancement and human development have an impact on the economic growth in Muslim countries. Controlling for political freedom and human capital, the data is compiled to identify the following dependent and independent variables. Islam represents percentage of Muslim population in the observed countries, polf represents political freedom, econf represents economic freedom, hd represents human development, hcap represents human capital and finally tfp represents total factor productivity or technology adaptation of Muslim countries. Research's dependent variable is economic growth or GDP and it is represented by grwth in the study. The expected sings of these variables are as follows:

\begin{tabular}{|l|l|}
\hline Coefficients & Expected signs \\
\hline Islam & $(+)$ \\
\hline Political Freedom (Polf) & $(+)$ \\
\hline Economic Freedom (Econf) & $(+)$ \\
\hline Human Development (Hd) & $(+)$ \\
\hline Human Capital (Hcap) & $(+)$ \\
\hline Total Factor Productivity (tfp) & $(+)$ \\
\hline
\end{tabular}

Table 1: The expected signs for the coefficients

\section{Descriptive Statistic}

Descriptive statistics help us illustrate the structure of the dataset, and further analyze the relationship between our dependent variable (economic growth) and independent variables (Islam, Economic Freedom, Political Freedom, Human Development, Human Capital and Adaptation of Technology). Scatter plot of economic growth in Muslim Countries and impact of Islamic (Figure I) seems to show a very weak positive relationship between the two variables. The result produced through this graph might not make intuitive sense at first since the observations seems to be scattered ${ }^{2}$.

2 Other graphical illustrations on the relationships between dependent and independent variables are included in Appendix B. 
Çamlıbel, D. A. (2014). What are the determinants of economic growth in Muslim countries? International Journal of Human Sciences, 11(1), 403-426. doi: 10.14687/ijhs.v11i1.2775

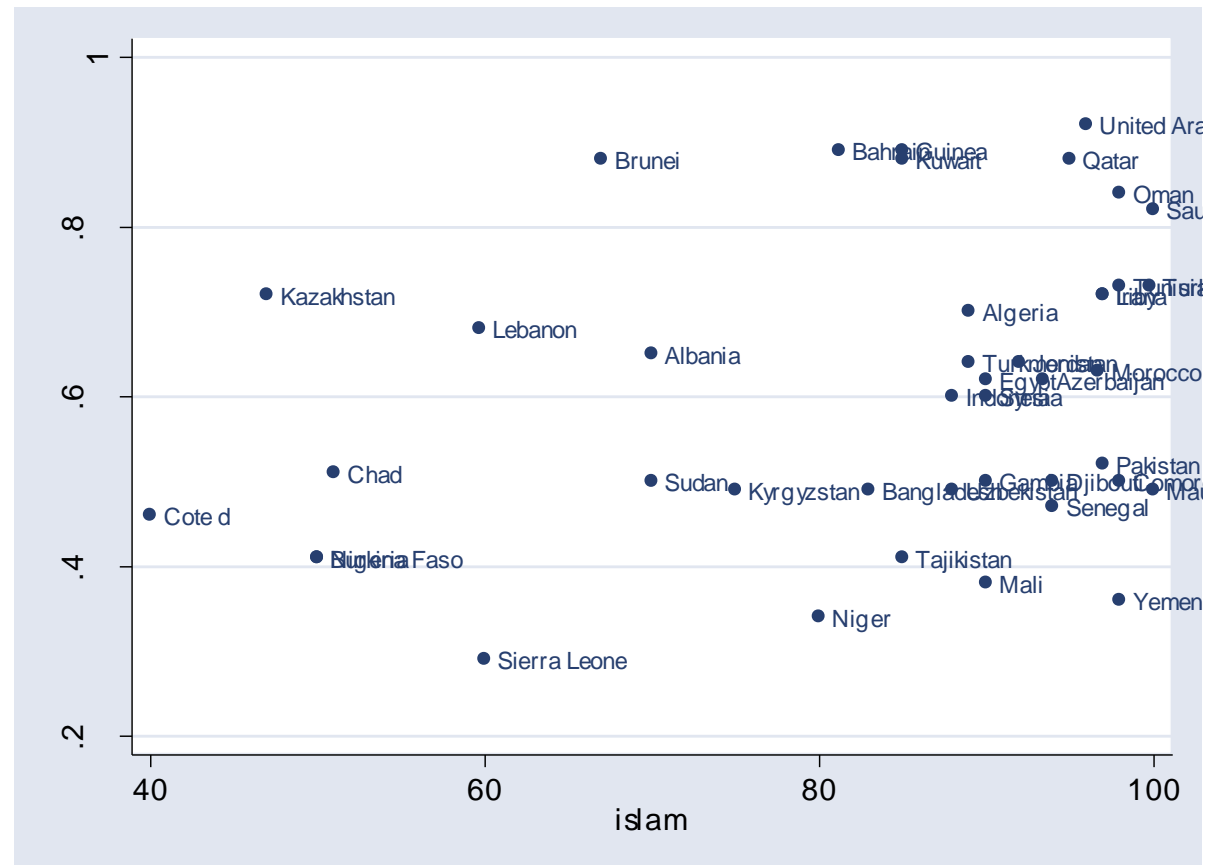

Figure 1: Relationship between Growth and Islam

\section{Analysis}

The mean percentage of the economic growth (GDP per capita) is $60 \%$ and the standard deviation is $17 \%$. The range demonstrates a pretty high spread with $29 \%$ (Sierra Leone) being the minimum and $92 \%$ (United Arab Emirates) maximum.

The mean value of Islam is $84 \%$ and the standard deviation is $16 \%$. The difference between minimum 40\% (Cote d'Ivoire) and maximum 100\% (Saudi Arabia and Mauritania) values of Islam is large.

The mean value of growth rate per worker Human Capital is 1.4\%. Standard deviation 1.5 and minimum human capital growth rate is -6.33 (Yemen) and maximum human capital growth rate is 3.39 (Tajikistan).

The mean value of TFP, which reflects technology is $1.2 \%$ and standard deviation, is $3.5 \%$. The differences between maximum and minimum values are -10.87 (Tajikistan) and 14.37 (Yemen) which shows large range in TFP rate.

The mean value of political freedom is 5.3 and according to the 1 to 7 scales this value tells us on average the Islamic countries are not politically free. Standard deviation is 1.3. The minimum value is 7 (several countries) and the maximum value is 2 (Mali and Senegal), this is a wide range of difference in terms of political freedom.

The mean value of economic freedom of Islamic countries is 53 . According to five bracket 0 to 100 scale this value tells us Islamic countries are mostly unfree. Standard deviation is 7.4. The minimum 
Çamlıbel, D. A. (2014). What are the determinants of economic growth in Muslim countries? International Journal of Human Sciences, 11(1), 403-426. doi: 10.14687/ijhs.v11i1.2775

value is 28.4 (Libya) and the maximum value is 73 (Bahrain), thus this is a wide range of difference in terms of economic freedom.

The mean value of Human Development is $63 \%$ and the standard deviation is $17 \%$. The differences between maximum and minimum values are 31\% (Niger) and $87 \%$ (Kuwait) ${ }^{3}$.

\section{The Hypothesis Test and Analysis}

In order to confirm the results drawn above from descriptive statistics a multivariate regression is applied to the data. The multivariate analysis offers the opportunity to test the impact of the variables introduced in the literature review. In addition, based on the theoretical explanations offered at an early part of this paper, multivariate analysis creates the conditions for hypothesis testing. The results on the hypothesis testing will in turn support some of the claims based on these theoretical explanations and literature review. In order to assess the impact of Islam, economic freedom, human development, technology on economic growth controlling for political freedom and human capital, an ordinary least squares (OLS) multivariate regression is an appropriate statistical method for this study.

\begin{tabular}{|l|l|l|l|}
\hline growth & Coef. & Std. Err. & $\boldsymbol{P}>/ \boldsymbol{t} /$ \\
\hline islam & .0001846 & .0010999 & $0.868^{*}$ \\
\hline hcap & .0762356 & .0277403 & 0.010 \\
\hline tfp & .0324521 & .0106203 & 0.005 \\
\hline polf & .0182195 & .0129768 & $0.171^{*}$ \\
\hline econf & .0073311 & .002594 & 0.009 \\
\hline hd & .4534842 & .1456981 & 0.004 \\
\hline cons & -.2493715 & .1665235 & 0.145 \\
\hline R-squared & 0.7218 & & \\
\hline Adj R squared & 0.6622 & & \\
\hline Prob > F & 0.0000 & \\
\hline
\end{tabular}

Variables are not significant both at $\mathrm{p}<0.10$ and $\mathrm{p}<0.05$ error level.

Table II: Regression on the Economic Growth in Muslim Countries

The original model for this data shows pretty good R-square and adjusted R-square, which are $72 \%$ and, $66 \%$ respectively. The results indicate that the model is performing well, and 72 and 66 percent of the variation in the level of percentage of growth in Muslim countries is explained by independent variables.

All signs, which we expected at the beginning of the study, fitted to coefficients of the empirical results and all variables are signed correctly as it was expected at the beginning of the study. Since probability of $\mathrm{F}$ is 0.000 , which is less than 0.05 thus one can reject Ho that all coefficients are 0 and one can also indicate that all the coefficients are together with significant. As a result one can

\footnotetext{
${ }^{3}$ For summary statistics please see Appendix A.
} 
Çamlıbel, D. A. (2014). What are the determinants of economic growth in Muslim countries? International Journal of Human Sciences, 11(1), 403-426. doi: 10.14687/ijhs.v11i1.2775

claim that the model is performing well. According to p-values hcap, tfp, econf, and hd are significant at $5 \%$ and $10 \%$ error level whereas Islam and polf and insignificant at both $5 \%$ and $10 \%$ error level.

In order to judge the effect of the independent variables on rate of economic growth in Muslim countries, substantive effects need to be calculated. According to Table II, substantive effect of the variables tell us; 1 unit increase in islam leads to 0 units change in economic growth, holding other variables constant. 1 unit increase in hcap leads to 0.07 change in economic growth, holding other variables constant. 1 unit increase in tlf leads to 0.03 change in economic growth, holding other variables constant. 1 unit increase in econf leads to 0.007 change in economic growth, holding other variables constant. 1 unit increase in hd leads to 0.453 increase in economic growth, holding other variables constant. Finally, 1 unit increase in polf leads to .018 increase in economic growth, holding other variables constant. Substantive effect of Islam is 0.011 , which is not substantial on the scale from 0.29 to 0.92 . Substantive effect of hcap is 0.74 , which is substantial on the scale from 0.29 to 0.92 . Substantive effect of tfp is 0.81 and tfp has the most substantive effect on the economic growth according to the scale from 0.29 to 0.92. Substantive effect of polf is 0.09 , which is not substantial on the scale from 0.29 to 0.92 . Substantive effect of econf is 0.32 , which is a little bit substantial on the scale from 0.29 to 0.92 . Substantive effect of hd is 0.25 , which is not substantial on the scale from 0.29 to 0.92 .

In order to be certain that OLS is a correct model for this hypothesis a series of tests have been run. The first test was the f-test to assure us that all variables included in the OLS are enhancing our model. The null hypothesis can be rejected because the p-value of the f-statistics is 0.0000 (less than 0.05), confirming that all variables -Islam, human capital, technology, political freedom, economic freedom, and human development-are jointly significant and enhancing the model.

Ramsey test for omitted variable bias has a p-value of $0.9234^{4}$, assuring us that all necessary variables are included in the model. The test for multicollinearity is negative with variance inflation factor (VIF) being $3.14^{5}$.

In the figure 2 the test on outliers shows that Yemen and Guinea are potential outliers and somewhat large residuals. Yemen has higher positive leverage, while Guinea has negative leverage

\footnotetext{
4 The value of 0.9234 is clearly higher than 0.05 which leads to the acceptance of the null hypothesis that the model has no omitted variables.

5 The value of 3.14 is greater than 10 which confirms there is no multicollinearity. The result on the other tests conducted for multicollinearity are presented in Appendix C.
} 
Çamlıbel, D. A. (2014). What are the determinants of economic growth in Muslim countries? International Journal of Human Sciences, 11(1), 403-426. doi: 10.14687/ijhs.v11i1.2775

on the coefficients. Libya and Tajikistan are also outliers but not show as high leverage or residuals as Yemen and Guinea ${ }^{6}$.

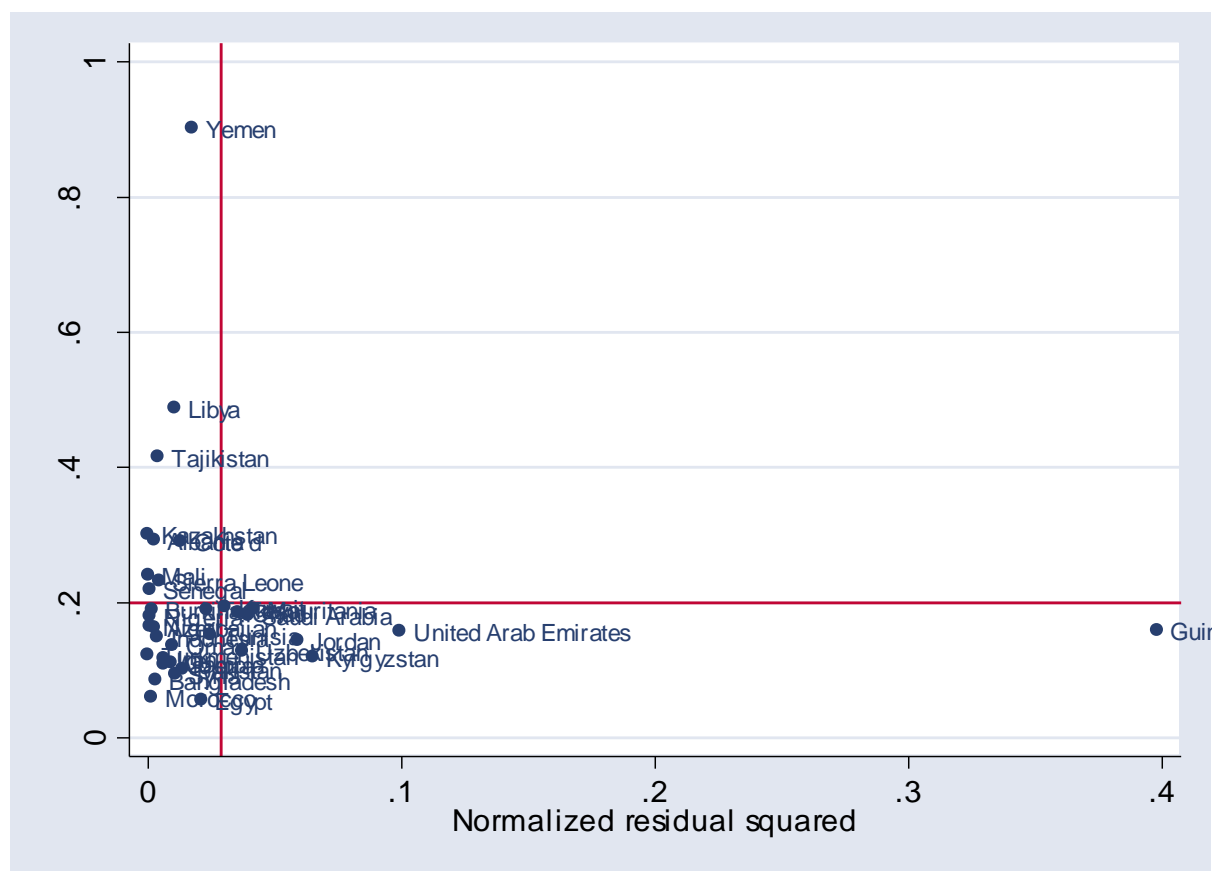

Figure 2: Lvr2plot

One can see in the figure 2 Yemen and Guinea could be potential outlier in this study ${ }^{7}$.

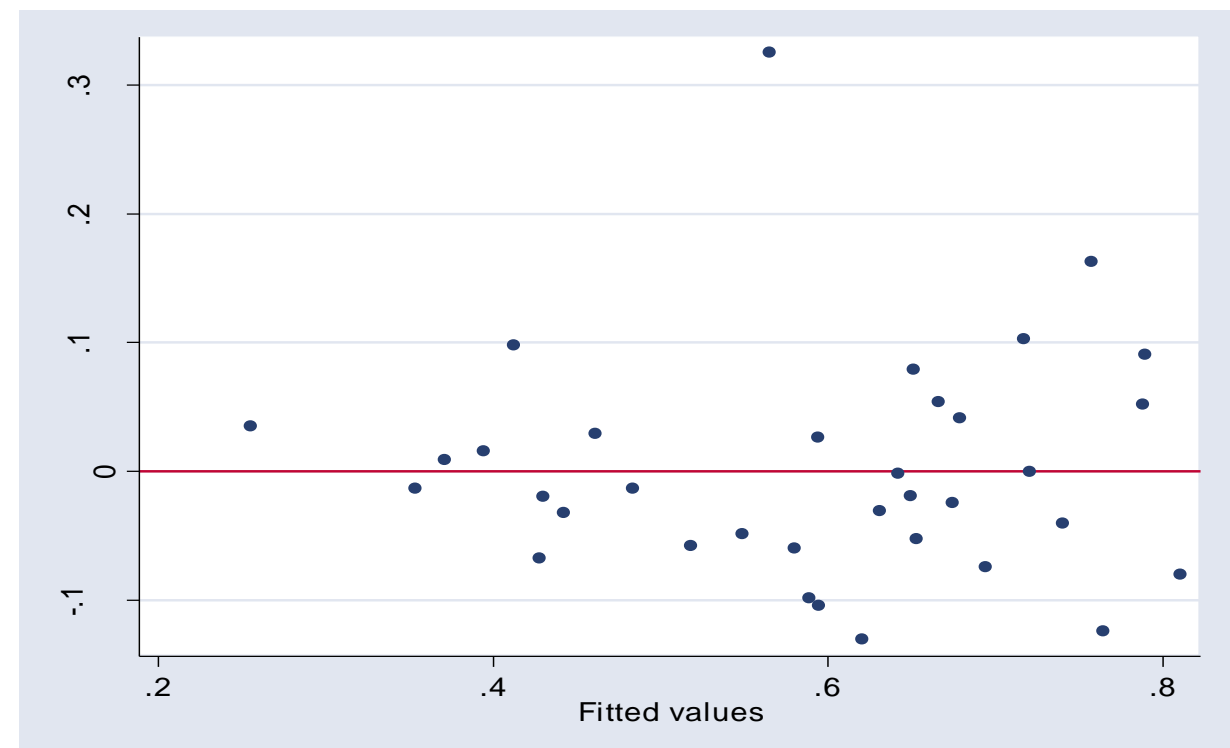

Figure 3: rvfplot

Informally, one can predict from Figure 3 that the residuals do not have a systematical relationship with predicted y and the residuals. Therefore, there is no sign for the heteroskedasticity problem; the distributions of residuals seem random. However, there are outliers in the research; thus, the

\footnotetext{
${ }^{6}$ Robust regression will be the final model in order to correct for the outliers
}

7 The rest of the diagnostic tests on outliers are included in Appendix D. 
Çamlıbel, D. A. (2014). What are the determinants of economic growth in Muslim countries? International Journal of Human Sciences, 11(1), 403-426. doi: 10.14687/ijhs.v11i1.2775

study may have a problem with both heteroskedasticity and normality of errors. Therefore, it is necessary to run the Breush-Pegan/Cook-Weisberg test (namely hettest) to check for heteroskedasticity. After performing the Breush-Pegan/Cook-Weisberg test in STATA ${ }^{\circledR}$, the result shows that there is no Heteroskedasticity thus Prob $>$ chi $2=0.3645$ which is obviously greater than $0.05^{8}$.

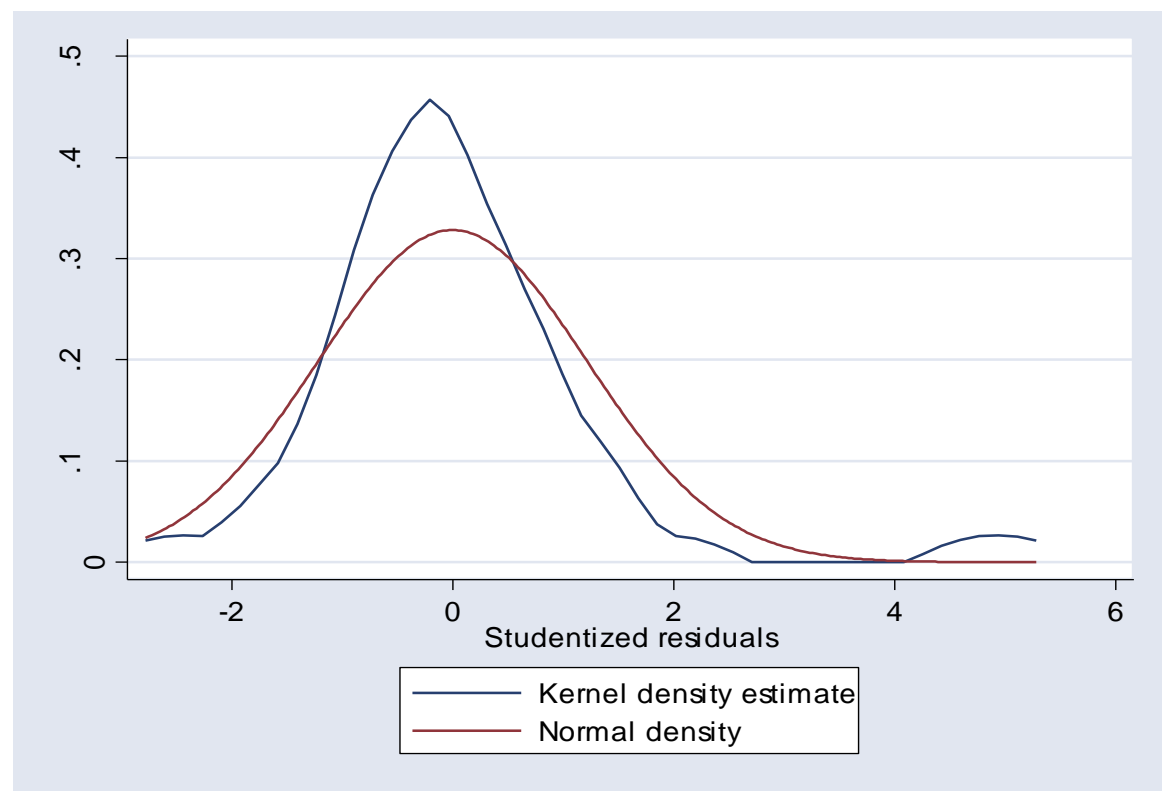

Figure 4: Kernel Density Plot

To ensure that study's OLS model is not violating normality of errors assumption one has to consider the studentized residuals, where mean is -0.002 (close to zero), variance is 1.21 (close to one), skewness is 1.477 (a bit skewed), and kurtosis is 9.12 (tall). Thus, both formal studentized residuals ${ }^{9}$ test and informal test for normality of error in the Figure 4 show that the data has a close to normal distribution. However, the Jarque-Bera test confirms research's previous assumptions about violation of normality of errors because of the outliers. Critical Chi-Squared with two degrees of freedom for the Jarque-Bera Test is 5.99, but calculated Chi-Squared for presented model, using actual residuals, is $72.89{ }^{10}$. Therefore, the presented initial model violates the assumption of normality of errors. In order to remedy the problem, Yemen, Guinea and United Arab Emirates, which were suspicious outliers, initially dropped than regression was performed again. However, the result did not change; the study still has a normality of error problem. Finally, in order to remedy the normality of error problem a robust regression was performed.

\footnotetext{
${ }^{8}$ In addition further tests are reported in Appendix E.

${ }^{9}$ See also Appendix F for studentized residuals

${ }^{10} \mathrm{JBtest}$ using actual residuals $=35^{*}\left[\left(1.77^{2} / 6\right)+\left((9.12-3)^{2} / 24\right)\right]=72.89$.
} 
Çamlıbel, D. A. (2014). What are the determinants of economic growth in Muslim countries? International Journal of Human Sciences, 11(1), 403-426. doi: 10.14687/ijhs.v11i1.2775

\section{The Final Model}

Since the initial model violated the OLS assumption of outliers and normality of error, the final model for hypothesis test is a multivariate robust regression, which gives less weight to outliers. The robust model's results still show that Islam and political freedom have no significant effect on economic growth in Muslim countries. The table III shows p-values for Islam and political freedom are 0.807 and 0.211 respectively which means that the null hypothesis of no effect of Islam cannot be rejected at either $10 \%$ or $5 \%$ error level. As in the initial model hcap and tfp are both significant $5 \%$ and $10 \%$ error level, however econf and hd only significant at 5\% but not at $1 \%$ error level after the robust regression.

\begin{tabular}{|l|l|l|l|}
\hline grwt & Coef. & Std. Err. & P>t \\
\hline islam & .0001846 & .000747 & 0.807 \\
\hline hcap & .0762356 & .0260561 & 0.007 \\
\hline tfp & .0324521 & .0102405 & 0.004 \\
\hline polf & .0182195 & .0142314 & 0.211 \\
\hline econf & .0073311 & .0027941 & 0.014 \\
\hline hd & .4534842 & .1960919 & 0.028 \\
\hline cons & -.2493715 & .1675844 & 0.148 \\
\hline R-squared & 0.7218 & & \\
\hline Prob > F & 0.0000 & & \\
\hline
\end{tabular}

Table III: Robust regression

The overall robust model performs as well as the initial model with $\mathrm{F}$ test being 0.000 and Rsquared being 0.72. Substantive effects of the independent variables on economic growth are the same as in the initial model because the Beta coefficients have not changed with a robust regression ${ }^{11}$.

\begin{tabular}{|l|l|l|l|l|}
\hline growth & Coef. & Std. Err. & Coef. & Std. Err. \\
\hline islam & .0001846 & .0010999 & .0001846 & .000747 \\
\hline hcap & .0762356 & .0277403 & .0762356 & .0260561 \\
\hline tfp & .0324521 & .0106203 & .0324521 & .0102405 \\
\hline polf & .0182195 & .0129768 & .0182195 & .0142314 \\
\hline econf & .0073311 & .002594 & .0073311 & .0027941 \\
\hline hd & .4534842 & .1456981 & .4534842 & .1960919 \\
\hline _cons & -.2493715 & .1665235 & -.2493715 & .1675844 \\
\hline R-squared & 0.7218 & & & \\
\hline Prob > F & $0.0000 \quad$ Table IV: Initial Model vs. Robust Model \\
\hline
\end{tabular}

${ }^{11}$ See Table IV :Initial Model vs. Robust Model. 
Çamlıbel, D. A. (2014). What are the determinants of economic growth in Muslim countries? International Journal of Human Sciences, 11(1), 403-426. doi: 10.14687/ijhs.v11i1.2775

\section{Conclusion}

The overall growth performance of the Muslim countries has been both complicated and described by a greater degree of volatility compared to other regions of the world. On the contrary to general belief that Islam hinders economic growth, this research showed that Islam by itself has no effect on economic prosperity in Muslim Countries. By using cross-country regression, it was found that the adaptation of technology and scientific innovations, investment to human capital, human development, and economic freedom are significant and necessary for economic growth in Islamic countries.

In Muslim countries technology and improvement of human capital should take priority over establishing economic freedom or human development. Accomplishment in human development and human capital are also very important for Muslim countries. Educational disparity is an essential issue among Muslim countries. Thus, Muslim countries need to take actions to close literacy gaps within their regions and also with the other regions of the World.

The causes of the bad economic performance of Muslim countries must be determined mainly in their ineffectively administered development process. Creating appropriate institutions and adopting suitable policies comprise the establishment for successful economic management.

However, this study could not find any significant effect of political freedom, but it might be prominent for the foreign investors because they will want to invest more economically and politically free countries. In other words, heavy government intervention into the market, high corruption in the country, ill defined property rights, civil war, undemocratic practices, instability of the country, heavy government regulations will discourage the foreign investor to invest in Muslim countries. Therefore, besides human development, human capital and adaptation of technology the Muslim countries should give importance to economic and political freedom.

For the future research, it is also necessary to include other religions for a better comparison of the economic performances among the different religions and cultures. It might also be useful to add the variable of geography, to see the impacts of geographical disadvantages or advantages on the countries' economic growth. Finally, it would be suitable to address and correct the problem of endogeneity that arises between variables such as economic growth and human development or economic growth and economic freedom. It is problematic to identify with certainty if economic growth leads to human development or human development leads to economic growth. 
Çamlıbel, D. A. (2014). What are the determinants of economic growth in Muslim countries? International Journal of Human Sciences, 11(1), 403-426. doi: 10.14687/ijhs.v11i1.2775

\section{References}

Ali, Abdiweli M. (1997). "Economic Freedom, Democracy and Growth." Journal of Private Enterprise 13 (Fall): 1-20.

Appleton, Simon and Teal, Francis (1998). "Human Capital and Economic Development" www.afdb.org/pls/portal/url/ITEM/F5411A7E9D7B3DB5E030A8C0668C612C viewed on May 5, 2007.

Baier, Scott L., Dwyer, Gerald P. Jr., and Tamura, Robert (2002). "How Important Are Capital and Total Factor Productivity for Economic Growth?" Federal Reserve Bank of Atlanta Working Paper 2002-2a, April.

Barlow, Robin (1982). "Economic Growth in the Middle East, 1950-72," International Journal of Middle East Studies 14, 129-57.

Barro, Robert and Xavier Sala-i-Martin (1995). Economic Growth. McGraw-Hill.

Barro, Robert J., and Rachel M. McCleary, (2002). "Religion and Political Economy in an International Panel," NBER Working Paper 8931. Cambridge: National Bureau of Economic Research.

Barro, Robert. J. (1991). “Economic Growth in a Cross-Section of Countries,” Quarterly Journal of Economics, 106(2), 407-443.

Barro, Robert. J. (1995), Determinants of Economic Growth, The MIT Press, London.

Becker, Gary S, Murphy, Kevin M and Tamura, Robert, (1990). "Human Capital, Fertility, and Economic Growth," The Journal of Political Economy, University of Chicago Press, 98(5), Part 2: The Problem of Development: A Conference of the Institute for the Study of Free Enterprise Systems, October, 12-37.

Benhabib, J. and M. Spiegel (1994). "The Role of Human Capital in Economic Development: Evidence from Aggregate Cross-Country Data," Journal of Monetary Economics, October, 34(2),143-173.

Collins, Susan M., and Barry P. Bosworth (1996). "Economic Growth in East Asia: Accumulation versus Assimilation," Brookings Papers on Economic Activity, 2, 135-91.

De Haan, Jakob and Sturm, Jan-Egbert (2000). "On The Relationship Between Economic Freedom And Economic Growth," European Journal of Political Economy, 16, 215-241.

De Vanssay, Xavier. and Spindler, Zane.A. (1994). "Freedom and growth: Do constitutions matter?," Public Choice, 78, 359-372.

Dieckmann, Oliver (1996). "Cultural determinants of economic growth: Theory and evidence," Journal of Cultural Economics, 20, (4), 297-320.

Farr, Ken; Lord, Richard A.; and Wolfenbarger, J. Larry (1998). "Economic Freedom, Political Freedom, and Economic Well-Being: A Causality Analysis". Cato Journal 18 (2), 247-262.

Fields, Bryan (2003). The Catholic Ethic and Global Capitalism, Aldershot, UK and Burlington, VT: Ashgate.

Foster, Andrew D and Rosenzweig, Mark R, (1995). "Learning by Doing and Learning from Others: Human Capital and Technical Change in Agriculture," Journal of Political Economy, University of Chicago Press, 103(6), December 1176-1209.

Gallup, J. L, J. Sachs and A. D. Mellinger. (1998). "Geography and Economic Growth," Paper prepared for the Annual Bank Conference on Development Economics, Washington, D. C., April 20-21.

Goldsmith, Arthur A. (1995). "Democracy, Property Rights, and Economic Growth." The Journal of Development Studies, 32 (2), December,. 157-74.

Griffin, K. and J.B. Knight (1990) "Human Development and the International Development Strategy for the 1990s" Macmillan: Basingstoke.

Guiso, Luigi; Sapienza, Paola, and Zingales, Luigi (2003). "People's Opium? Religion and Economic Attitudes," Journal of Monetary Economics, 50, (1), January, 225-282. 
Çamlıbel, D. A. (2014). What are the determinants of economic growth in Muslim countries? International Journal of Human Sciences, 11(1), 403-426. doi: 10.14687/ijhs.v11i1.2775

Gwartney, James D.; Lawson, Robert A.; Holcombe, Randall G. (1999). "Economic Freedom and the Environment for Economic Growth." Journal of Institutional and Theoretical Economics 155 (4): 1-21.

Huntington, Samuel P. (1996). The Clash of Civilizations and the Remaking of World Order. New York: Touchstone.

Inglehart, Ronald and Wayne E. Baker (2000). "Modernization, Cultural Change, and The Persistence of Traditional Values." American Sociological Review, 65(1), 19-51.

Kuran, Timur (2004). "Why the Middle East is Economically Underdeveloped: Historical Mechanisms Of Institutional Stagnation," Journal of Economic Perspectives, 18, (3), 71-90.

Landes, David, S. (1999). The Wealth and Poverty of Nations: Why Some Are So Rich and Some Are So Poor. New York: Norton.

Lipset, S. Martin, (1959). "Some Social Requisites of Democracy: Economic Development And Political Legitimacy," American Political Science Review, 53, 69-105.

Mankiw, N. Gregory; Phelps, Edmund S.; and Romer, Paul M. (1995). The growth of nations. Brookings Papers on Economic Activity, 1995, (1), 25th Anniversary Issue, 275-326.

Noland, Marcus (2002). "Religion, Culture, and Economic Performance," Institute for International Economics, Washington, September.

Noland, Marcus (2005). "Religion and Economic Performance. World Development," 33, 12151232.

North, Charles and Gwin, Carl, (2004). "Religious Freedom And The Unintended Consequences Of State Religion," Southern Economic Journal 71, 103-117.

Ranis, Gustav, (2004). Human Development and Economic Growth, Yale University, Center Discussion Paper No. 887.

Reischauer, Robert D. (1994). Recent Developments In The Theory Of Long-Run Growth: A Critical Evaluation, October.

Romer, Paul, (1990). "Endogenous Technological Change," The Journal of Political Economy, 98, (5), Part 2: The Problem of Development: A Conference of the Institute for the Study of Free Enterprise Systems. (October), S71-S102.

Sachs, Jeffrey. D., and Andrew. M. Warner (1997). "Sources of Slow Growth in African Economies," Journal of African Economies, 6, 335-376.

Scully Gerald, W. and Slottje, Daniel, J. (1991). "Ranking Economic Liberty Across Countries," Public Choice, 69, 121-152.

Scully, Gerald.W. (1992) Constitutional Environments and Economic Growth. Princeton, N.J.: Princeton University Press.

Stern, Nicholas (1991). "The Determinants of Growth," The Economic Journal, 101, (404), January, 122-133.

UNDP (1990), Human Development Report, Oxford: Oxford University Press.

Zipfel Jacob, (2004). "Determinants Of Economic Growth" Florida State University D-Scholarship Repository, Article number 20. October, viewed on May 5, 2007 http://dscholarship.lib.fsu.edu/undergrad/20. 
Çamlıbel, D. A. (2014). What are the determinants of economic growth in Muslim countries? International Journal of Human Sciences, 11(1), 403-426. doi: 10.14687/ijhs.v11i1.2775

\section{Appendix A}

\begin{tabular}{|l|l|l|l|l|l|l|}
\hline Variable & Obs & Mean & Std. Dev & Min & Max & Median \\
\hline Growth & 45 & .6071111 & .1723846 & .29 & .92 & .62 \\
\hline Islam & 44 & 83.92727 & 16.78412 & 40 & 100 & 90 \\
\hline Human Capital & 39 & 1.404615 & 1.526649 & -6.33 & 3.39 & 1.43 \\
\hline Total Factor Productivity & 39 & -1.204359 & 3.586091 & -10.87 & 14.37 & -.85 \\
\hline $\begin{array}{l}\text { Political Freedom } \\
\text { Economic Freedom }\end{array}$ & 48 & 5.3125 & 1.370762 & 2 & 7 & 6 \\
\hline Human Development & 40 & 53.2525 & 7.431395 & 28.4 & 73 & 54.3 \\
\hline
\end{tabular}

\section{Appendix B}

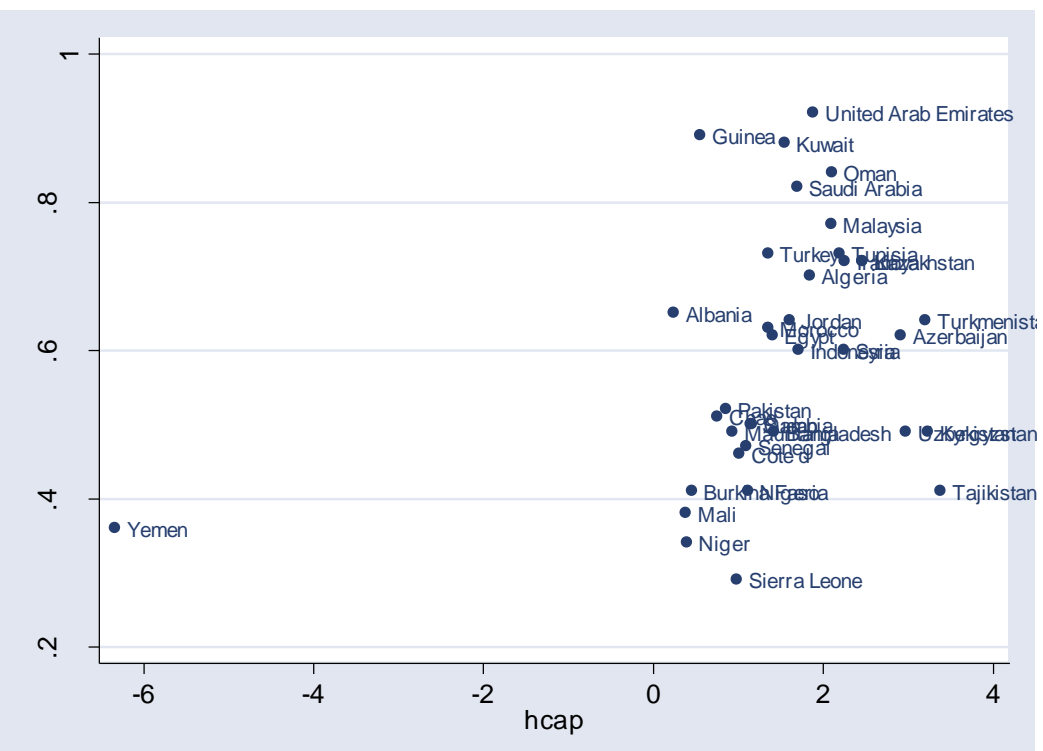

Figure 5 Relationships between Economic Growth and Human Capital per Worker

The relationship seems to be positive. Higher rates of (+ positive) Human Capital correspond to higher levels of Economic Growth. 
Çamlıbel, D. A. (2014). What are the determinants of economic growth in Muslim countries? International Journal of Human Sciences, 11(1), 403-426. doi: 10.14687/ijhs.v11i1.2775

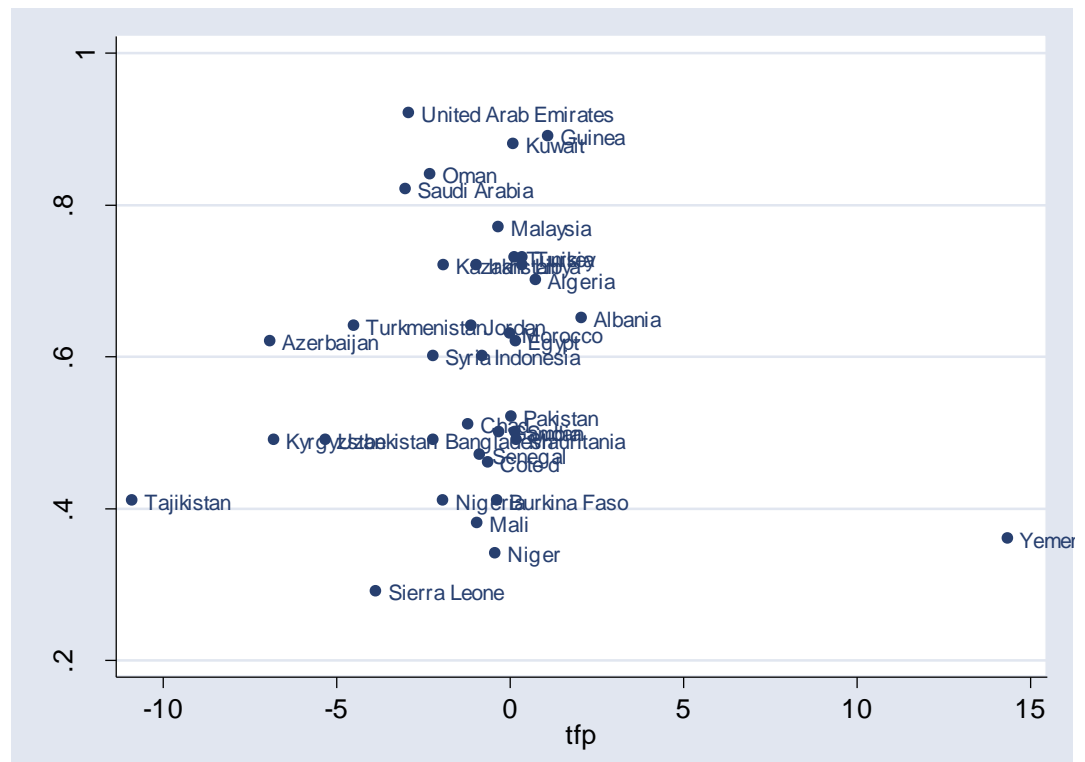

Figure 6 Relationships between Economic Growth and Total Factor Productivity (adaptation of technology) The relationship seems to be positive. Higher ( + positive) weighted averages of technology adaptation correspond to higher levels of Economic Growth.

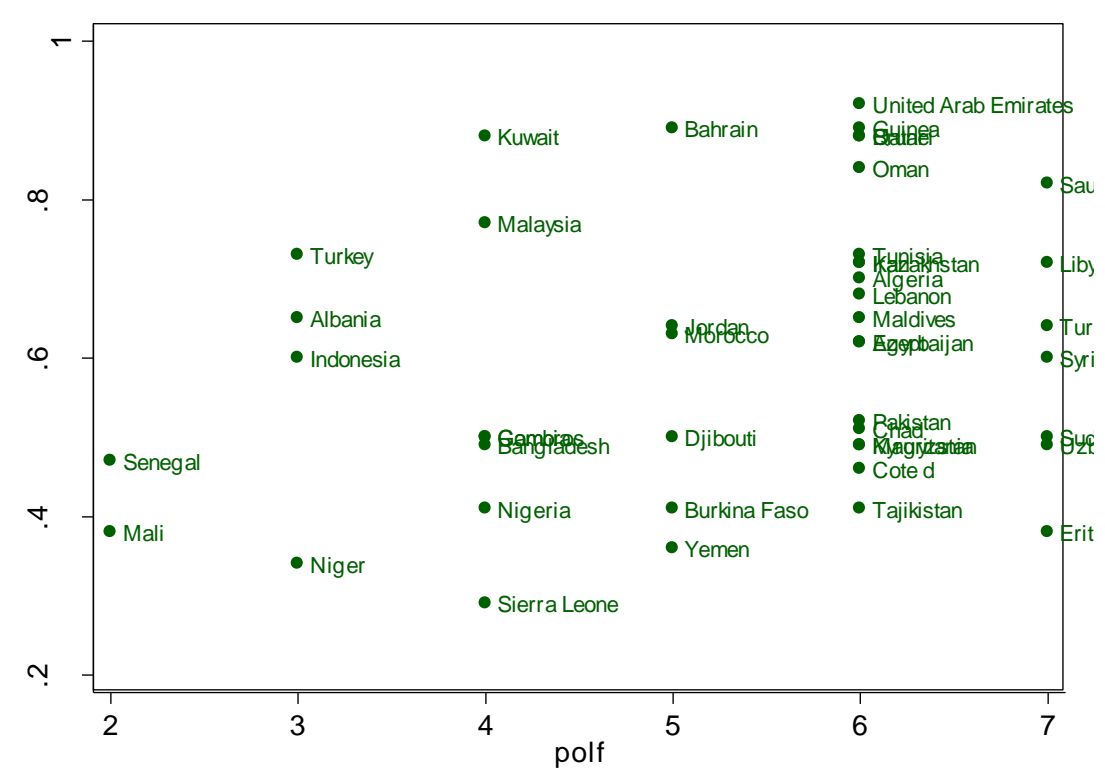

Figure 7 Relationships between Economic Growth and Political Freedom

It is not as obvious to derive a relation between economic growth and political freedom from this graph. 
Çamlıbel, D. A. (2014). What are the determinants of economic growth in Muslim countries? International Journal of Human Sciences, 11(1), 403-426. doi: 10.14687/ijhs.v11i1.2775

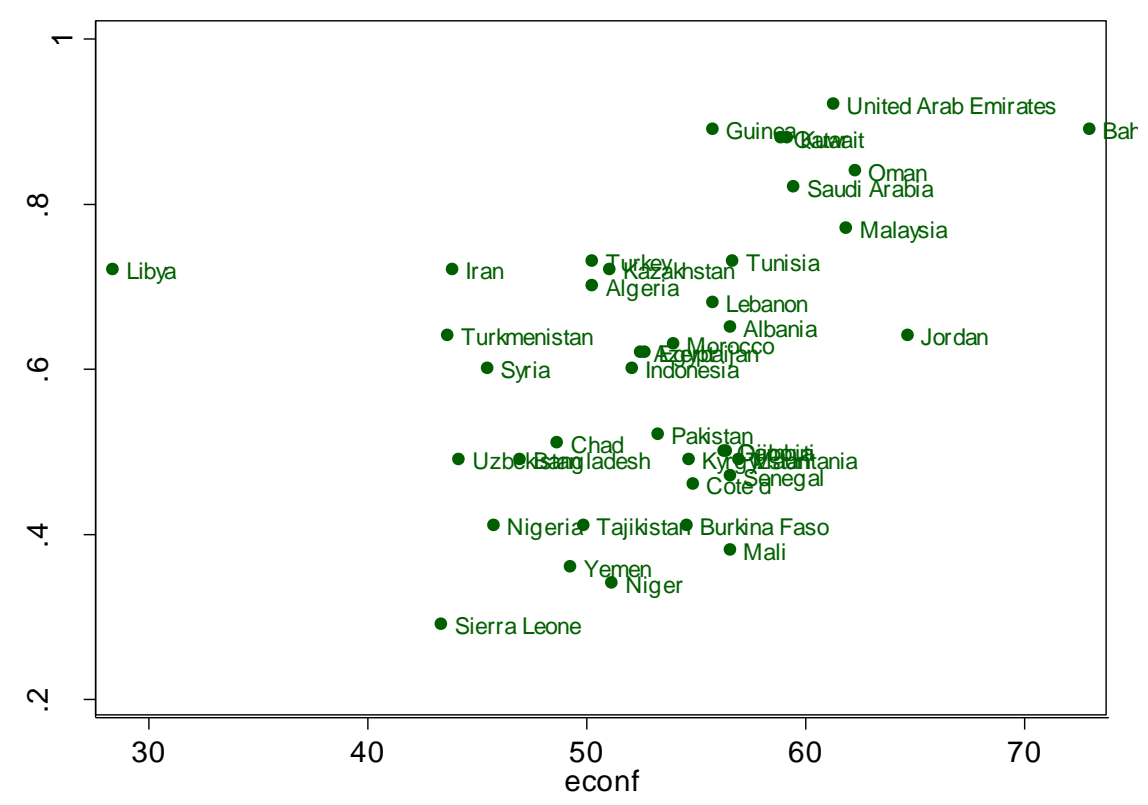

Figure 8 Relationships between Economic Growth and Economic Freedom

The relationship seems to be positive. Higher scores of economic freedom correspond to higher levels of Economic Growth.

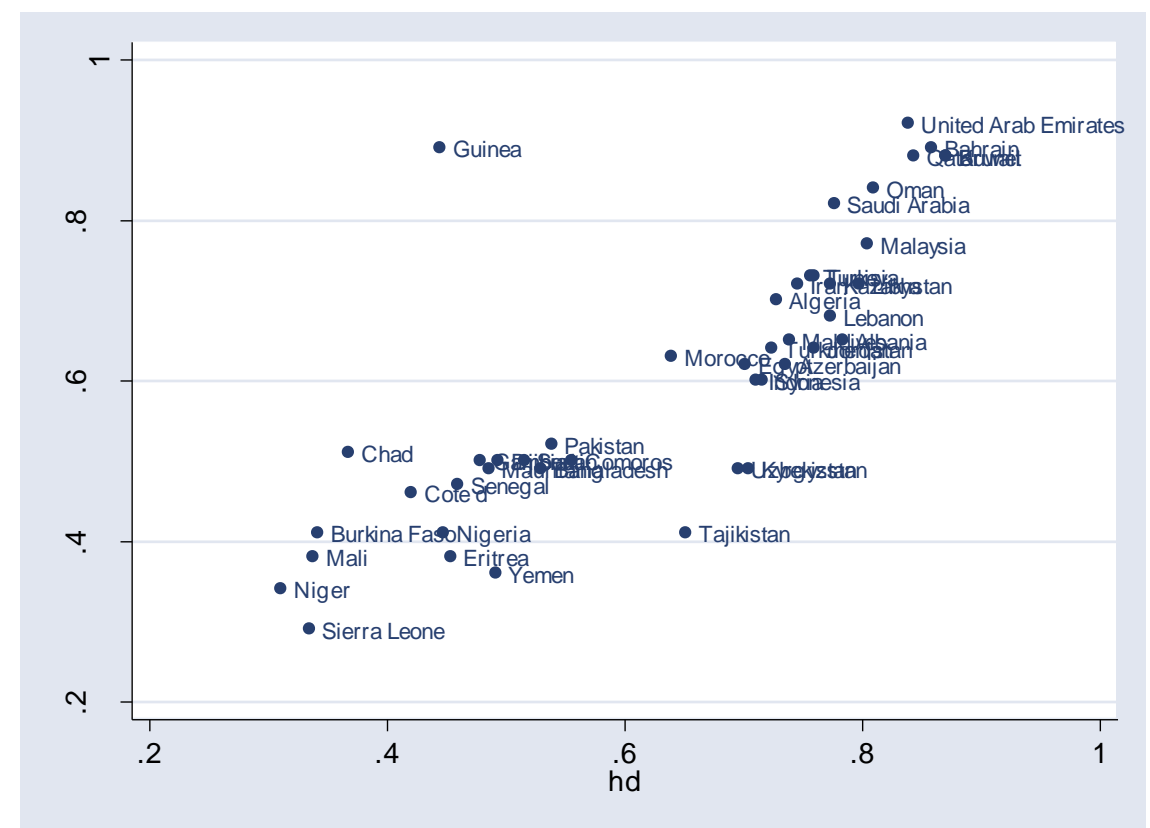

Figure 9 Relationships between Economic Growth and Human Development

The relationship seems to be positive. Higher values of human development correspond to higher levels of Economic Growth. 
Çamlıbel, D. A. (2014). What are the determinants of economic growth in Muslim countries? International Journal of Human Sciences, 11(1), 403-426. doi: 10.14687/ijhs.v11i1.2775

\section{Appendix C}

\section{(Additional diagnostics on multicollinearity)}

\begin{tabular}{|c|c|c|c|c|c|c|}
\hline & islam & hcap & tfp & polf & econf & hd \\
\hline islam & 1.0000 & & & & & \\
\hline hcap & 0.0182 & 1.0000 & & & & \\
\hline tfp & 0.1208 & -0.8715 & 1.0000 & & & \\
\hline polf & 0.0824 & 0.3323 & -0.2288 & 1.0000 & & \\
\hline econf & 0.1114 & -0.0986 & 0.0414 & -0.2248 & 1.0000 & \\
\hline hd & 0.4356 & 0.4490 & -0.1717 & 0.3797 & 0.0666 & 1.0000 \\
\hline & & & & & & \\
\hline
\end{tabular}

Table VI

1) Correlation between independent variables: Table indicates that there is no correlation close to 1 between any of the variables; therefore there is no multicollinearity

2) The $R^{2}$, from the regression of each independent variable on the rest of the independent variables, are all less than the $\mathrm{R}^{2}$ of the original model.

\section{Appendix D}

\section{(Diagnostic tests on outliers)}

Hat value is the measure of the leverage. These countries are with large hat values Afghanistan, Bahrain, Brunei, Comoros, Djibouti, Eritrea, Iraq, Lebanon, Libya, Maldives, Malaysia, Qatar, Somalia, Tajikistan, Yemen.

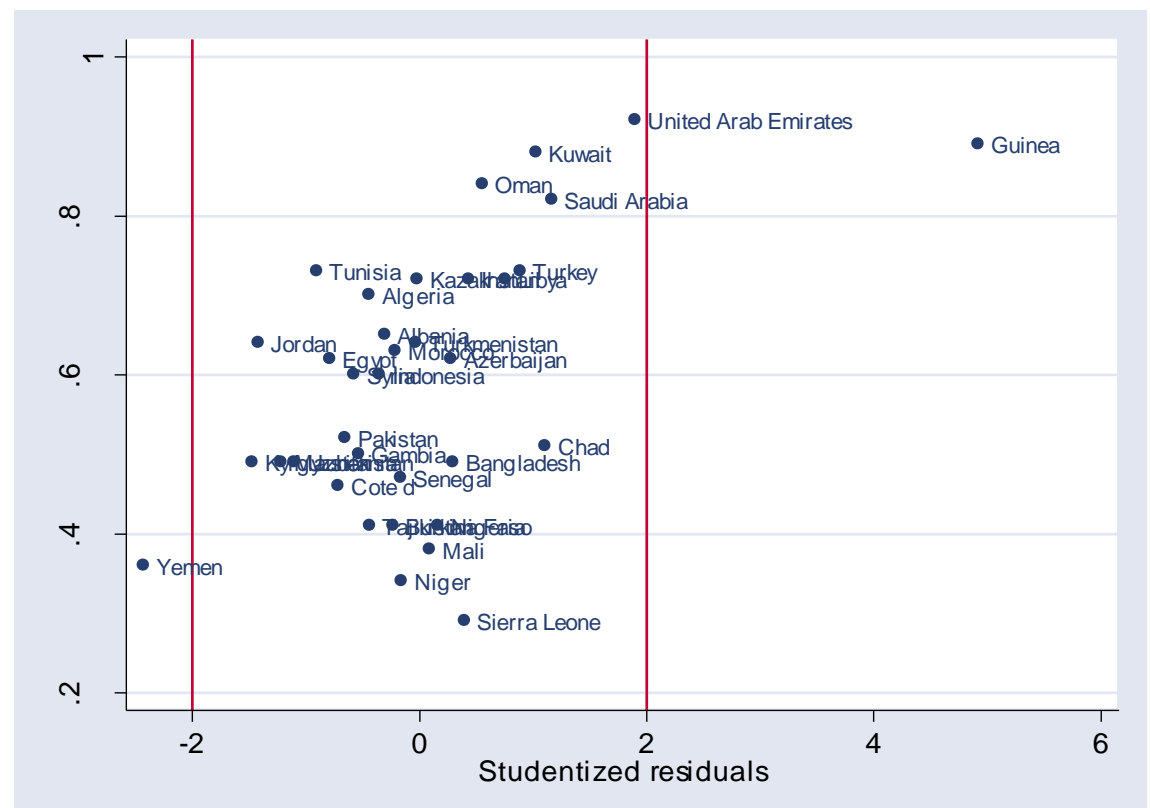

Figure VII : studentized residuals

We can use studentized residuals to test if there is a significant intercept change in the model. If the observation fall outside of $(-2,2)$ range, then we say they could be outliers. In this case, Yemen and Guinea could be outliers. 
Çamlıbel, D. A. (2014). What are the determinants of economic growth in Muslim countries? International Journal of Human Sciences, 11(1), 403-426. doi: 10.14687/ijhs.v11i1.2775

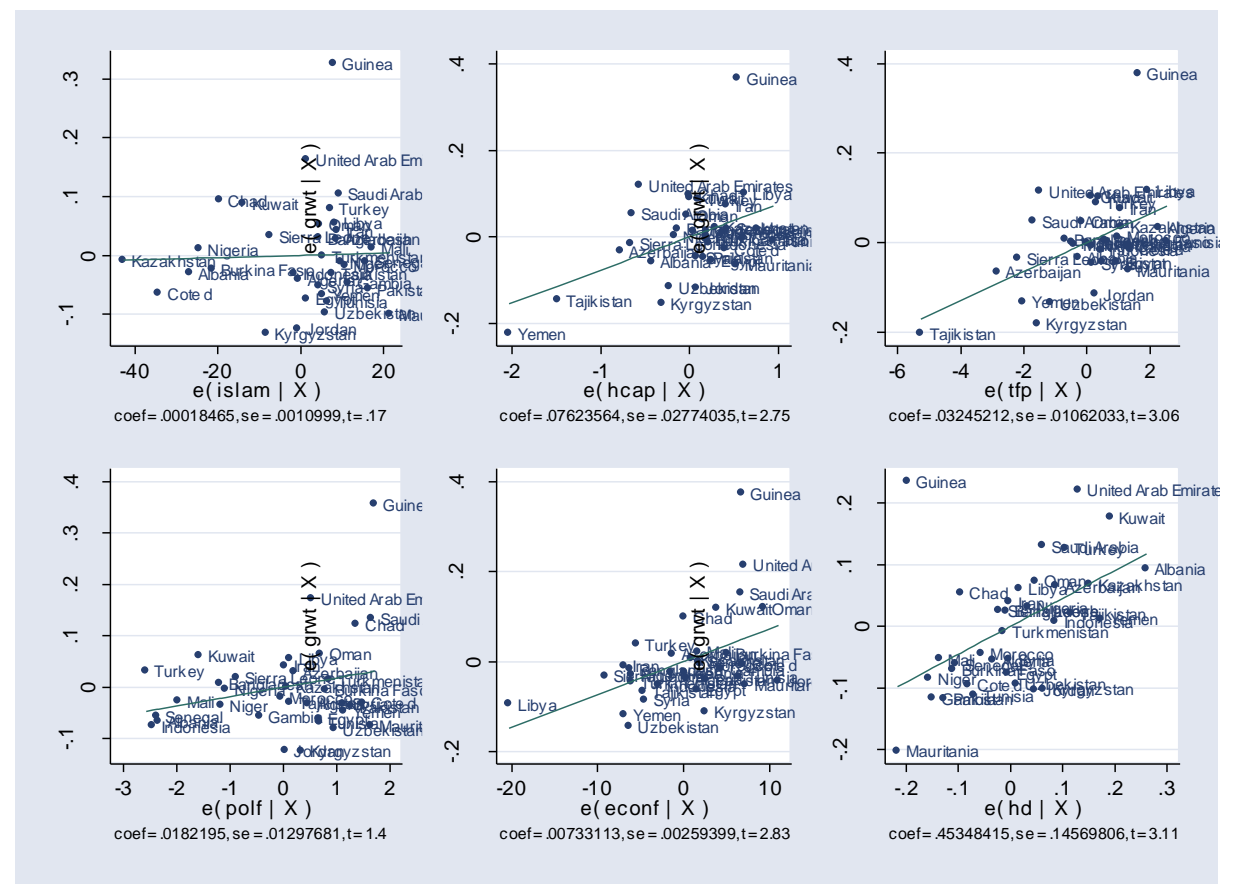

Figure VIII: avplot

Avplots tell us the relation between dependent variable and each of independent variable, adjusting for the other variables. As outlier will be distant from other observations. Guinea, Yemen, and United Arab Emirates might be outliers.

Furthermore, after measuring the influence of each independent variable on individual coefficients by running the DF Beta for each independent variable, STATA lists numerous outliers. DF Islam and DFpolf: Afghanistan, Bahrain, Brunei, Comoros, Djibouti, Eritrea, Guinea, Iraq, Lebanon, Maldives, Malaysia, Qatar, Somalia, and Sudan. DFhcap and DFtfp: Afghanistan, Bahrain, Brunei, Comoros, Djibouti, Eritrea, Guinea, Iraq, Lebanon, Maldives, Malaysia, Qatar, Somalia, Sudan, and Yemen. DF econf: Afghanistan, Bahrain, Brunei, Comoros, Djibouti, Eritrea, Guinea, Iraq, Lebanon, Maldives, Malaysia, Qatar, Somalia, Sudan, UAE and Yemen. DF hd: Afghanistan, Bahrain, Brunei, Comoros, Djibouti, Eritrea, Guinea, Iraq, Lebanon, Maldives, Malaysia, Qatar, Somalia, Sudan, UAE and Mauritania.

\section{Appendix E}

\section{(Additional Diagnostic test for heteroskedasticity)}

\begin{tabular}{|l|l|l|l|}
\hline Imtest & \multicolumn{2}{l|}{} \\
\hline Source & chi2 & df & p \\
\hline Heteroskedasticity & 30.55 & 27 & 0.2899 \\
\hline Skewness & 7.69 & 6 & 0.2618 \\
\hline Kurtosis & 1.15 & 1 & 0.2843 \\
\hline Total & 39.39 & 34 & 0.2414 \\
\hline & Table VII (IM-test) & \\
\hline
\end{tabular}

Cameron \& Trivedi's decomposition of IM-test shows there is no heteroskedasticity since its $\mathrm{p}$ value is greater than 0.05 . 


\section{Appendix F}

\section{(Diagnostic test for normality of error)}

\begin{tabular}{|c|c|c|c|c|}
\hline & Studentized & residuals & & \\
\hline & Percentiles & Smallest & & \\
\hline $1 \%$ & -2.426033 & -2.426033 & & \\
\hline $5 \%$ & -1.467458 & -1.467458 & & \\
\hline $10 \%$ & -1.212865 & -1.415352 & Obs & 35 \\
\hline $25 \%$ & -.6504164 & -1.212865 & $\begin{array}{l}\text { Sum of } \\
\text { Wgt. }\end{array}$ & 35 \\
\hline \multirow[t]{2}{*}{$50 \%$} & -.162946 & & Mean & -.002124 \\
\hline & & Largest & Std. Dev. & 1.215432 \\
\hline $75 \%$ & .4375663 & 1.111638 & & \\
\hline $90 \%$ & 1.111638 & 1.169932 & Variance & 1.477275 \\
\hline $95 \%$ & 1.901097 & 1.901097 & Skewness & 1.770354 \\
\hline $99 \%$ & 4.926775 & 4.926775 & Kurtosis & 9.121734 \\
\hline
\end{tabular}

